\title{
DEVELOPMENT POLICY ADVISORY PUBLIC SERVICE IN AGRICULTURE IN THE REPUBLIC OF SERBIA ${ }^{2}$
}

\begin{abstract}
Under the advisory public services in agriculture mean all institutions that publicly declare that they are in the service of agriculture. The main objective of the establishment of these services is to facilitate agricultural production. These services include: various institutes such as the Institute of Agriculture seed, protection from disease and dr., Agricultural services, veterinary, anti-hail service, Department of Pomology, National Institute of Viticulture.

In the countries of Southeast Europe, among which is Serbia and such services are still underdeveloped and are in the phase of constitution. It is necessary to support the development of these services because it is a regulated market is part of an integrated rural development.

Drawing on the positive experience of developed countries in the EU and beyond, and in connection with the establishment and operation of agricultural advisory services, all the countries of South East Europe during the last decade of the 20th century established this service. The fact that in the formation of agricultural extension has not implemented a unique organizational model, and that in the current functioning of these services are not everywhere achieved satisfactory results, indicating, among other things, that there are no universal solutions for all situations.
\end{abstract}

Key words: public services, agricultural extension, Serbia.

JEL classification: Q1, Q10, Q16.

\section{ПОЛИТИКА РАЗВОЈА САВЕТОДАВНИХ ЈАВНИХ СЛУЖБИ У ПОЉОПРИВРЕДИ У РЕПУБЛИЦИ СРБИЈИ}

\begin{abstract}
Апстракт
Под саветодавним јавним службама у пољопривреди подразумевамо све оне институцฺије које се јавно декларишу да су у служби аграра. Главни ичиљ оснивања ових служби је олакшавање аграрне производње. У ове службе спадају: разни институти за пољопривреду попут института за семе, заштиту од болести и др., пољопривредне службе, ветеринарске станице,

\footnotetext{
${ }^{1}$ zoki@medianis.net

${ }^{2}$ This paper work is result of the project No. 46006 - III „Sustainable agriculture and rural development in function realizing strategic goals of the Republic of Serbia in framework of Danube region", financing by the Ministry of Education and Science of the Republic of Serbia.
} 
противградна служба, заводи за воћарство, завод за виноградарство.

Код земаља југоисточне Европе, међу којима се налази и Србија овакве службе су још увек недовољно развијене и налазе се у фази конституисања. Неопходно је подржати развој ових служби јер управо уређено тржиште представља део интегралног руралног развоја.

Ослањајући се на позитивно искуство развијених земаља ЕУ и шире, а у вези са оснивањем и радом пољопривредних саветодавних служби, све државе Југоисточне Европе су током последње деценије 20. века основале ове службе. Чињеница да у формирању пољопривредног саветодавства није примењен јединствен организациони модел, као и да у досадашњем функиионисағу ових служби нису свугде остварени задовољавајући резултати, указује, поред осталог, и на то да не постоје универзална решења за све ситуаџије.

Кључне речи: јавне службе, пољопривредно саветодавство, Србија.

\section{Introduction}

Progress in agriculture and rural development can not be imagined without consulting the public service, which is organized in a modern way. The primary function of such an organized public service in agriculture is to enable easier transfer of knowledge. In conditions when Serbia became a candidate country for membership in the European Union should create the conditions for our agriculture in a smooth way to adapt to the new conditions. In this sense, the state has to make a large number of laws and development documents, as well as to establish institutions that will ensure the harmonization with the European Common Agricultural Policy. It all means that the field of agricultural extension in Serbia exposed to the challenges of reform. An important step in this direction was made with the entry into force of the "Law on the provision of advisory and professional activities in the field of agriculture." This law indicates that it is busy right direction in modernizing and increasing the efficiency of public advisory services in agriculture in Serbia.

\section{The development of public services in the CEE countries}

Training and consulting services for the development of agriculture is in constant progress. There is a great motivation for these services to transfer knowledge to farmers. Training provided by counselors and information support services themselves is focused primarily on technology and production aspects of agriculture. Many advisors in the CEE countries specialize in certain areas of technical assistance.

In the case of Bulgaria, we see how public services are organized to support agriculture. In the first place there is the National Centre for Agricultural Sciences, National Service then selection and reproduction, and the Ministry of Agriculture and Forestry. And the National Agricultural Advisory Service began operations in 1995. This service provides free information, advice, consultation and training for farmers in 28 regional offices. (Millns, 2006, p. 30). 
A novelty in some countries in transition represents the emergence of private advisory services for agriculture. The first country that started with the development of private services, Estonia. In this country the government from its funds enable the financing of knowledge transfer by agents of various private services to various associations of farmers. Advisory work is related to the transfer of technology. Farmers use this opportunity to enter into contracts with various private advisory services. State advisory services continued to remain operational. Their primary task is to provide a variety of benefits advice to poorer farmers. (Norton, 2004, p. 409). State-owned all the other laboratories of the Ministry of Agriculture, the State Veterinary Service and the Agricultural Faculty. (Csaki, Lekman, 2000, p. 240).

Private agricultural departments were formed in Hungary, Slovakia and the Czech Republic.

The experiences of different countries in the CEE on the question of public services for agriculture are quite different.. All of these countries the vast majority of cases, have public services for agriculture under state ownership. These services are oriented on providing basic advice by agents or authorized representatives of these services, and related agrotechnical issues. Poor organization of these services at the state level affects their efficiency and ability to provide adequate advice to farmers. Limitations in the civil service in state ownership can best be seen in the case of Polish. In this country there is a large public service system that provides limited support to farmers due to poor pay, because of inadequate transfer fees and the high administrative burden. (Sutton, 2008, p. 21).

\section{The development of public services for agriculture in Serbia}

According to the Law on Agriculture and Rural Development, which was adopted 29.05.2009. year and entered into force on 03.06.2009. was governed by the existence of public services for agriculture. In the part which refers to the shape of structural incentives to be more precise, under Article 12 of this Law points out that: "Mere institutional support to the type of incentives that encourage research programs in agriculture, programs of advisory services, promotion of agriculture, Agricultural Market Information System of the Republic of Serbia, and other programs. "(Official Gazette of RS, no. 41/09, p. 73). In early May 2010, adopted the Law on the provision of advisory and professional activities in the field of agriculture. This law regulates the conditions and methods for advisory and professional activities in the field of agriculture, the Register of agricultural advisors, training of agricultural advisors and agricultural producers, development planning advisory services in agriculture, as well as other issues of importance for advisory work in agriculture. (Official Gazette of RS, no. 30/10).

\section{Agricultural - Advisory Service}

The development of agriculture in modern conditions requires a well organized service dealing with the study and improvement of production technology, transfer of scientific achievements in practice and scientific institutions dealing with education of agricultural professionals. 
The main role of agricultural extension, as well as measures of agricultural policy, is focused on providing advice and information to farmers in the acceptance and application of new knowledge. The work of these services can be performed directly by certain specialized institutions, but also through various media resources such as brochures, newspapers, radio, television, internet. So, the agricultural department has an obligation to connecting farmers with educational and scientific institutions. (Vujicic, Ristić, 2006, p. 69).

Agricultural extension in Serbia is realized on two levels. These are the Agricultural Advisory Service of AP Vojvodina and Agricultural Extension Service Central Serbia. The adoption of the Ordinance on the organization and operation of the Provincial Agricultural Extension Service in 2006, virtually created the conditions for the start of the Provincial Agricultural Services. The main objective of the adoption of this Regulation was to increase the presence of advisors in the field of agricultural producers. Of a total of thirty-five agricultural extension services in the Republic of Serbia, in the area of AP Vojvodina is actively thirteen. Holders of advisory activities in agriculture Serbia are agricultural extension services, institutes, veterinary, private companies and consultants, as well as local NGOs. Two institutions that largely coordinated development of agricultural advisory services, including the creation of legislation and funding, the Ministry of Agriculture, Forestry and Water Management of the Republic of Serbia and the Provincial Secretariat for Agriculture, Forestry and Water Management of AP Vojvodina. (Markovic, \& Thomas, 2010, p. 62).

Table 1. Agricultural Advisory Service in the Republic of Serbia

\begin{tabular}{|c|c|c|}
\hline Number & City & Nam \\
\hline 1. & Niš & $\begin{array}{l}\text { Poljoprivredna savetodavna i stručna služba /Agricultural advisory and } \\
\text { professional service Niš, d.o.o. }\end{array}$ \\
\hline 2. & Valjevo & $\begin{array}{l}\text { Poljoprivredna savetodavna i stručna služba / Agricultural advisory and } \\
\text { professional service Valjevo, d.o.o. }\end{array}$ \\
\hline 3. & Vranje & $\begin{array}{l}\text { Poljoprivredna savetodavna i stručna služba/ Agricultural advisory and } \\
\text { professional service Vranje, d.o.o. }\end{array}$ \\
\hline 4. & Kraljevo & $\begin{array}{l}\text { Poljoprivredna savetodavna i stručna služba/ Agricultural advisory and } \\
\text { professional service Kraljevo, d.o.o. }\end{array}$ \\
\hline 5. & Jagodina & $\begin{array}{l}\text { Poljoprivredna savetodavna i stručna služba/ Agricultural advisory and } \\
\text { professional service Jagodine, d.o.o. }\end{array}$ \\
\hline 6. & Mladenovac & $\begin{array}{l}\text { Poljoprivredna savetodavna i stručna služba/ Agricultural advisory and } \\
\text { professional service Mladenovac, d.o.o. }\end{array}$ \\
\hline 7. & $\begin{array}{l}\text { Kosovska } \\
\text { Mitrovica }\end{array}$ & $\begin{array}{l}\text { Poljoprivredna stručana služba/ Agricultural Extension Service Kosovska } \\
\text { Mitrovica d.o.o. }\end{array}$ \\
\hline 8. & Kragujevac & $\begin{array}{l}\text { Poljoprivredna savetodavna i stručna služba Agricultural advisory and } \\
\text { professional service Kragujevac, d.o.o. }\end{array}$ \\
\hline 9. & Kruševac & $\begin{array}{l}\text { Poljoprivredna savetodavna i stručna služba/ Agricultural advisory and } \\
\text { professional service Kruševac, d.o.o. }\end{array}$ \\
\hline 10. & Leskovac & $\begin{array}{l}\text { Poljoprivredna savetodavna i stručna služba Agricultural advisory and } \\
\text { professional service Leskovac, d.o.o. }\end{array}$ \\
\hline 11. & Užice & $\begin{array}{l}\text { Poljoprivredna savetodavna i stručna služba/ Agricultural advisory and } \\
\text { professional service Užice, d.o.o. }\end{array}$ \\
\hline
\end{tabular}




\begin{tabular}{|c|c|c|}
\hline 12. & Negotin & $\begin{array}{l}\text { Poljoprivredna savetodavna i stručna služba/ Agricultural advisory and } \\
\text { professional service Negotin, d.o.o. }\end{array}$ \\
\hline 13. & Novi Pazar & $\begin{array}{l}\text { Poljoprivredna savetodavna i stručna služba/ Agricultural advisory and } \\
\text { professional service Novi Pazar, d.o.o. }\end{array}$ \\
\hline 14. & Čačak & $\begin{array}{l}\text { Poljoprivredna savetodavna i stručna služba / Agricultural advisory and } \\
\text { professional service Čačak, d.o.o. }\end{array}$ \\
\hline 15. & Pirot & $\begin{array}{l}\text { Poljoprivredna savetodavna i stručna služba / Agricultural advisory and } \\
\text { professional service Pirot, d.o.o. }\end{array}$ \\
\hline 16. & Smederevo & $\begin{array}{l}\text { Poljoprivredna savetodavna i stručna služba/ Agricultural advisory and } \\
\text { professional service Smederevo, d.o.o. }\end{array}$ \\
\hline 17. & Požarevac & $\begin{array}{l}\text { Poljoprivredna savetodavna i stručna služba/ Agricultural advisory and } \\
\text { professional service Požarevac, d.o.o. }\end{array}$ \\
\hline 18. & Šabac & Poljoprivredna savetodavna i stručna služba Šabac, d.o.o. \\
\hline 19. & Zaječar & $\begin{array}{l}\text { Poljoprivredna stručana služba/ Agricultural Extension Service Zaječar - } \\
\text { Agroznanje d.o.o. Zaječar }\end{array}$ \\
\hline 20. & Prokuplje & $\begin{array}{l}\text { Poljoprivredna savetodavna i stručna služba/ Agricultural advisory and } \\
\text { professional service Šabac, d.o.o. }\end{array}$ \\
\hline 21. & Loznica & $\begin{array}{l}\text { Poljoprivredna stručana služba/ Agricultural Extension Service Poljosavet } \\
\text { d.o.o. Loznica }\end{array}$ \\
\hline 22. & Padinska Skela & SSPP Padinska Skela \\
\hline 24. & Subotica & Poljoprivredna stručana služba / Agricultural Extension Service Subotica \\
\hline 25. & Bačka Topola & $\begin{array}{l}\text { Poljoprivredna savetodavna i stručna služba/ Agricultural advisory and } \\
\text { professional service Bačka Topola, d.o.o. }\end{array}$ \\
\hline 26 & Vršac & Enološka stanica /Enological stations Vršac \\
\hline 27. & Kikinda & $\begin{array}{l}\text { Poljoprivredna stručna služba/ Agricultural Extension Service Kikinda, } \\
\text { d.o.o. }\end{array}$ \\
\hline 28. & Novi Sad & Poljoprivredna stručana služba/ Agricultural Extension Service Novi Sad \\
\hline 29. & Pančevo & \\
\hline 30. & Ruma & Poljoprivredna stručana služba/ Agricultural Extension Service Ruma \\
\hline 31. & Senta & Poljoprivredna stručana služba/ Agricultural Extension Service Senta \\
\hline 32. & $\begin{array}{l}\text { Sremska } \\
\text { Mitrovica }\end{array}$ & $\begin{array}{l}\text { Poljoprivredna stručana služba/ Agricultural Extension Service Sremska } \\
\text { Mitrovica }\end{array}$ \\
\hline 33. & Sombor & Poljoprivredna stručana služba/ Agricultural Extension Service Sombor \\
\hline 34 & Vrbas & Poljoprivredna stručana služba/ Agricultural Extension Service Vrbas \\
\hline 35. & Zrenjanin & Poljoprivredna stručana služba/ Agricultural Extension Service Zrenjanin \\
\hline
\end{tabular}

Source: http://psss.rs/

According to a new law on the provision of advisory and professional activities in the field of agriculture under Article 5 is determined to advisory work in agriculture can be performed by companies founded by the Republic of Serbia, which are registered in the Register of Business Entities to perform other services in agriculture, technical tests and 
analysis and consulting and management and which have employed agricultural adviser. Advisory jobs in agriculture can be practiced by other legal entities and entrepreneurs if they are in the register of business entities registered for performing other services in agriculture, technical testing and analysis and consulting and management if their employee agricultural adviser. (Official Gazette of RS, no. 30/10, p. 136-137).

Giving opportunities to entrepreneurs and other legal entities and private companies to provide advisory services is new to the organization of extension and advisory services working in the field of agriculture. This feature is already present in the countries that are in the European Union as we have already pointed out. Persons engaging extension aims to help the farmer to overcome negative practices. On the other hand it is understood that the farmer accepts their advice. Throughout this business clients have control over the work of his advisers. In the event that the work is not a high-quality advisors farmer may lose trust in the advisor and the more it does not engage.

\section{Professional paper - forms, objectives, organization}

Under the new law on the provision of advisory and professional activities in the field of agriculture under Article 7 are precisely regulated professional activities in agriculture. That implies that legal persons and entrepreneurs engaged in advisory work in agriculture can perform professional tasks in agriculture in accordance with this Law and other regulations.

As professional jobs in agriculture to jobs that are determined as such by the law and other regulations in the field of farming, plant health, animal husbandry and other areas of agriculture. Professional work in agriculture of interest to the Republic of Serbia shall be done in accordance with the annual program adopted by the Government.

Funds for professional work in agriculture are provided by the law governing the annual budget of the Republic of Serbia. Professional work in agriculture from the autonomous province, in the autonomous province shall be conducted in accordance with the programs adopted by the autonomous region. Professional work in agriculture for the unit of local government shall be performed in accordance with the programs for the territory of the local unit makes local governments. (Official Gazette of RS, no. $30 / 10)$.

Advisory jobs in agriculture carried out in order to raise the general level of knowledge of farmers and their awareness, increasing the competitiveness and modernization of agricultural production, increase the profitability of production and product quality, the introduction of organic food production, encouraging interest association of farmers, preservation of natural resources, environmental protection and improving the living conditions and culture of life in the countryside, and therefore rural development.

Advisory jobs in agriculture according to the above mentioned Act are precisely defined and they include:

- providing technical assistance in the implementation of scientific achievements and new technologies;

- $\quad$ providing expert advice and services, transfer of practical knowledge and skills for technological improvement of production technology; 
- familiarizing farmers with good agricultural practice;

- perform demonstration experiments in various fields of agriculture;

- Training of agricultural producers to manage farms and keeping accounting records of the holding;

- $\quad$ assist in the affirmation of rural development;

- providing advice on plant protection on the basis of data forecasting and reporting services;

- stimulating interest association and entrepreneurship in agriculture;

- providing advice and making proposals for the expansion of economic activities as a supplementary activity on the farm;

- making recommendations in livestock;

- providing advice and recommendations on the rational use of land;

- providing advisory assistance in other areas for which farmers express interest.

In Serbia, the professional agricultural service organized at the national, provincial and regional levels. On the territory of central Serbia operates twenty-one agricultural expert service (http://www.psss.rs/news.php) on the territory of thirteen. (http://www.polj.savetodavstvo.vojvodina.sr.gov.yu/index.php?module=subjects\&f unc=listpages\&subid=1) The role of central government advisory service has and the Institute for Science Application in Agriculture.

The current situation in professional services shows that it is necessary to reform these services due to certain problems that are present in them. Let us mention just a few of the problems: regular contact with farmers is still weak, budget financing service is also not regular, and eventually material equipment in service is inadequate to actual needs. In addition, unfavorable age and qualification structure of the employees of this ministry. Also, insufficient activity of educational and research institutions as well as the cooperation itself service to them. The information system is still not sufficiently efficient and developed. Achieved is poor communication with suppliers of agriculture, processing industry, financial institutions, trade and agricultural policy subjects.

Be sure that the results achieved in the agricultural production of our country have been better with a better functioning of the relationship between science, agricultural extension services and agricultural producers, especially farmers. The aim of agricultural extension services should be to connect the agricultural farm with educational and scientific research institutions.

Transfer of agricultural innovation are engaged in agricultural station, agricultural institutes, research institutes, development services, research and development centers in agricultural combines. In Serbia there are 10 veterinary and specialized institutes, more than 350 veterinary clinic, about 290 veterinary stations and 5 centers for artificial insemination. (Đekić, 2010, p. 194-195).

According to all presented, should, priority is given to scientific research and education based on their agricultural producers, as well as the development of agricultural advisory services, which represents support in initiating and developing specific production.

In Serbia, unfortunately ever-present problems of funding, both for scientific research and agricultural production, while the education and association in the background. In the agribusiness sector extension is one of the important factors of 
modernization business. In support of this statement must be given a confirmed fact that investment in the extension (and agricultural research) yields about $40 \%$ of the average wage rate, which is "much more than other investments in agricultural development." (Van den Ban, Hawkins, 1996, p. 13). The modern agricultural means of modern technology. In this regard, in order to meet the standards of organic production, it is necessary that new consultants have highly specialized knowledge.

Ideal advisors (ie. SMS - Subject Matter Specialist) implies the knowledge of specific areas such as socio-economic consulting, environmental extension, as well as the introduction of new regulations and standards in the EU. Consequently, the assumption of a successful agricultural extension is continuous training of advisors and exchange business experience and innovation through associations. In this regard, the existence of strategic planning development and connectivity AKIS-a (Sistema knowledge and information in agriculture) and various training centers advisers. (Mihailovic, Simonovic, 2008, p. 262)

These can be special centers for this purpose, but the most common are the universities, research institutes, schools and various institutions, depending on the needs of advisors, provide additional training. (Janković, 2006, p. 584). In this way, consultants enrich their knowledge and enriching business experience.

In the end we want to stay that is closer to the needs of agriculture extension services necessary to decentralization and networking consulting work. Support for this process should be decentralization of the advisory bodies of individual ministries, which would create conditions for adequate answers to the needs of individual farms and agricultural enterprises, and the possibility of a partnership approach to solving business problems. Also for the effective allocation of resources needed is a regional exchange of consultants, including interconnection advisory work in Serbia. Agricultural enterprises and manufacturers are still not well informed about the role and importance of advisory services have. For example, more than $40 \%$ of rural households have never heard of a counseling service, $24 \%$ of households do not know how to obtain them, while only $8 \%$ of them regularly consults with this service. (Bogdanov, 2007, p. 143-144). These facts clearly indicate what should be the primary focus and advisory services and agricultural sectors, as well as the state, and to the improvement of education and awareness in this area because of it would benefit everyone. This means that the advisory organization received more business and thus more funds, and to intensify its development. Farmers and companies would, using the services of advisory organization, it accelerated its development. And finally, the state would, if nothing else, get richer sources of financing Budget.

\section{Conclusion}

Public advisory services in agriculture, representing a rate of agrarian policy. Their importance is posebon oželeda in that they represent a kind of link between science and practice. For all these reasons, the work of these agencies must be taken more seriously than it is with us to this day the practice. The adoption of laws and documents is a positive development, but not sufficient progress in the development of this issue. Namely, that the quality of legislation and / or strategies came to the fore, it is necessary to provide conditions for their practical application. 
Just a modern extension service is one of the key drivers of agricultural development and rural confirm the experience of most developed countries of the world, whose advisory services have a long tradition and an important place in the structure of the agricultural policy. We should not forget the fact that the rate of return on funds invested in agricultural extension between 40 and 50\% and that the period of economic return of these funds is less than the production cycle. On the other hand, CEE countries in the vast majority of cases the public authorities for agriculture which are owned by the state. These services are oriented on providing basic advice by agents or authorized representatives of these services that are related to agrotechnical issues. Poor organization of these services at the state level affects their efficiency and ability to provide adequate advice to farmers.

From the world of states, we can conclude that the investment performance of the agricultural extension, from the national to the local level, should not be seen as a cost but as an investment in the future. The elements that are essential to laying the foundations of modern savatodavne services are: application of legislation, institution building, investment in the formation of high-quality advisory personnel. Only in this way organized advisory service would enable the agricultural population in our country to infomiše, utilize and improve their potential, knowledge and skills, and improve the quality of production to a higher level.

\section{References}

Bogdanov N. (2007): „Mala ruralna domaćinstva u Srbiji i ruralna nepoljovredna ekonomija“", UNDP, Beograd, 143-144.

Vujičić M., Ristić L. (2006): „Ekonomika poljoprivrede“, Kragujevac, 69.

Van den Ban, A.W., Hawkins, H., S. (1996): “Agricultural Extension", Blackwell Science, UK, 13.

Đekić S. (2010): „Agrarni menadžment“, Ekonomski fakultet, Nis, 194-195.

Janković D., (2006): Organizacioni modeli poljoprivrednog savetodavstva u Nemačkoj, Ekonomika poljoprivrede, Tematski broj, Beograd, 584.

Markovic, K., \& Tomas, M. Zakonodavno-pravni okvir kao jedan od uslova za razvoj poljoprivrednog savetodavstva. Agroekonomika Agrieconomica, 62.

Михаилович Б., Симонович 3., (2008): „Некторы видах сельскохзяйственных кооперативов Франции“"Вестник Елецкого Государственного Университета, выпуск 19, Елец, Россия, 262.

Mihailović, B., Savić, M., \& Katić, B. (2007). Konsalting, održivi razvoj i organska proizvodnja-perspektiva Srbije. Industrija, 35(4), 81-94.

Millns J., (2006): „Promoting Farmer entrepreneurship through producer organization in Central and Eastern Europe“, Food and Agricultural Organization of the United Nations, Rome, 30.

Novkovic, N., Vasiljevic, Z., \& Matkovic, M. (2013). E-Concept of an agricultural extension service. Poljoprivreda i Sumarstvo, 59(2), 187. 
Norton R.D., (2004): „Agricultural Development Policy: concepts and experiences“, Food and Agricultural Organization of the United Nations, John Wiley\&Sons Ltd, West Sussex, 409.

Simonovic Z. (2014): Upravljanje agrarom Srbije u tranziciji, IEP, Beograd,

Sutton W. R. (2008): „Integrating Environment into Agriculture and Forestry: Progress and Prospects in Eastern Europe and Central Asia“, The World Bank, Washington D.C., 21.

Csaki C., Lekman Z.(2000): ,Structural Change in the Farming Sectors in Central and Eastern Europe“, World Bank Technical Paper no 465, Washington, 239-240.

Службени гласник РС, бр. 41/09, 73.

Службени гласник РС, бр. 30/10 .

http://www.psss.rs/news.php (05.02.2016.)

http://www.polj.savetodavstvo.vojvodina.sr.gov.yu/index.php?module=subjects\&fun $\mathrm{c}=$ listpages\&subid $=1(05.02 .2016)$ 